his death will bring sorrow to the hearts of many of his fellow pioneers. In acts of unostentatious charity and real kindness, he was ever foremost, and many a settler of those early days has had occasion to share his bounty, and remember him with gratitude. His effurts in the improvenent of Muscatine, were ever strenuous, honorable and effective, and that city owes her present pusition and prosperity more to him than to any other single individual. Ile died as he had lived, a good man, leav. ing the priceless heritage of an untarnished name to his children.-State Press, lowa City, Feb. 8.

From the Dubuque Times, March 21.

\title{
MEETING OF THE OLD SETTLERS OF DUBUQUE.
}

The Old Settlers' meeting, in the rooms of the Board of Education yesterday afternoon, "called for the purpose of expressing sympathy with the fanily of the late James L. Langworthy, and their appreciation of the loss the community has sustained in his death," was largely attended. It was probably the largest gathering of Old Settlers ever held in Dubnque, and was a no:able assemblage, the like of which is rarely seen in any community. A nobler looking body of men never convened in Iowa. Many of them were here, associates of Mr. Langworthy, when in all the rest of the State there was not a whitte man. To look in upon the meeting was worth a journey of miles.

The following are the names of gentlemen present. Nearly all of them have been here twenty-five years, and several of them over thirty years.

P. A. Lorimier, C. H. Booth, Matthew McNear, Patrick Quigley, John king, J. D. Bush, A. Levi, W. Weigley, Timothy Mason, Lichard Waller, D. A. Mahony, P. Waples, J. H. Bartlett, Thos. Waters, Geo. O. Karrick, L. A. Thomas, Wm. 
Andrew, J. R. Goodrich, Jacob Christman, H. C. Pierce, J. H. Emerson, Richard Bonson, W m. Myers, A. McDaniel, Wm. Lorimer, John D. Grafforr, Wm. A. Jones, T. C. Roberts, John O'Regarn, James Pratt, C. J. Cummings, John Dougherty, John Goldthorpe, Wm. W aters, Purdy Willi:.nson, John Palmer, James Peacock, Warner Lewis, Win. G. Stewart, A. D. Anderson, Benjamin Rupert, N. V. Descelles, P. McGeon, H. L. Stout, H. A. Wiltsę. Rubert Rogers, Wm. H. Robbins, R. O. Chaney, John Blake, Joseph Brunskil', Jesse Yount, R. C. Waples, F. E. Bissell, Hugh Treanor, Jesse M. Harrison, M. McNamara, Wm. Lawther, Plait Smith, Geo. W. Jones, John Waters, A. Graham, W. W. Hanilton, Richard Cox, Thomas Hardie, F. Guerin, Nathias Ham, Wm. Carter, John Spencely, Wm. Wilson, John Bell, Tumothy Davis, E. D. Turner, M. Morgan.

The meeting was called to order by H. L. Stout, Esq., upon whose motion Peter A. Lorimier, E-q., was elected President.

Mr. Lorimier upon taking the chair, remarked that those present knew the sad event which had occasioned the meeting. He said he had known Mr Langw rily for forty years. He had found him honorable in every business trausaction. Mr. L. was a valuable member of the cummunity. When he heard of his death he felt deep sorrow, and his heart overflowed in sympathy for his family.

On motion of Mr. Bonson, C. Childs, Esq, was appointed Secretary of the meeting.

On motion of fen. Wiltse, the Chair was sequested to appoint a Committee of Five to draft res lutions expressive" of the feelings of the Settlers in regard to Mr. Langworthy's death. The Chair appointed Messr. Wiltse, Mason, Lewis, J. H. Emerson, and Judge Burt as such Committee.

The Committea retired, and during their absence several gentlemen were called upon to address the meeting.

Captain Jesse M. Harrison said his acquaintance with Mr. Lang worthy commenced thirty-six years ago. Ile had known him iutimately, and esteemed him highly. He alwass considered him an estimable citizen. His sucial qualities endear- 
ed him to m ny, and those who kaew him be-t esteemed him most. No man could be mistaken as to Mr. lanworthy's opinious. He was always frank and on spoker. Capt. H. concluded by again alluding to the deceased in high terms of praise.

Platt Smilh, Esq., said he condd eudorse all Captain Harrison had said, and would add more. Mr. Langworthy was generous in many respects. He not only cared for his own family, but there were several others indebted to him for education and the comforts of life. Mr. Smith added several other remarks concerning the character of the deceised, and then, allading to the meeting, said there is a bond of sympathy betwee; the old setrlers which does not exi-t between those who came here af er laws were made and society was regulated. The old settlers were frank in their speech, there was no deceit about them. They were extremely ubliging to each other. They would walk twenty miles to do a neighbor a service, where a man would not walk a sqnare to do it now. Mr. Smith concluded with the remark that Mn:. Langworthy was one of the frankest and best of the inen who settled the country.

Gen. Jones said he sympathized with all present in the loss of Mr. Langworthy. He knew him we l. Ile served with him in the Black-Uauk war and knew him to be a brave man. His death was distressing not only to his family, but to every old setrler present. Gien. Junes remarked that he himself came to Sinsinawa Mound in 1827. Lie built a $\log$ finrnace there in 1528, and came to Dubnque to purcha-e of the Indians the ore which they dug ont of the hills with their tomahawks. He conid say that he came to the of her side of the river (where Dunlieth now is) with the first wagon that ever approached Dubaqne. The Indians brought their ore to him in canoes, and lie had opened a road to Sininawa for the purpose of transporting it. Again alluding to the Black-1lawk war, he said the Pre-ident participated in it as a Vaptan. Lucius and James L. Langworthy also served in t'ie canpaign, and so did Gen. Lewis. Gen. Junes conciuded with au ellusion to the 
rapidity with which the old settlers must soon fo!low $\mathrm{Mr}$. Langworthy to the last resting place.

Here the Committee returned and presented the following report :

Whereas, It has pleased God in his Providence to remove from life Mr. James L. Langworthy, for a quarier of a century our valued friend and fellow ciizen, for whom our assuciation enterrained a high regard, and whose dealh pron!j,1s us 10 affectionately cherish and rerpect his memor ; therefine,

Resolved, That, in the sudden death of Mr. Langworth $v$, the North-West has parted with one of its tirst settlers, and Dubuque with its oldest citizen.

Resolied, That no old or new citizen ever cherished the reputation, or labored for the prosperity of onr ci $y$, more fervently and tirelersly than did Mr. Langwoithy. Dubuque was his home. and he loved it wi h an nndivided aff ction.

Resolved, That as a citizen le was en erprising, as a neighbor he was cour enus, and as a mim he was aliove reproach; while as a husband and father his devoiion was alınost without a parallel.

Resolved, That we tender to the bereaved family of the deceased our heartielt sympathy.

Resolved. That a Cummittee of Five be appointerl to preparo a biographical sketch of the deceased for publ cation.

Gen. Warner l.ewis, in secon ling a moti n for the adoption of the resolutions, said he had kuown Mr Langwort!y forty years. He (Mr Lewis) came to the Gulena region in the spring of 1827 . He was with Mr. Langworthy in the Winnebago war of that year. They camped one night at the furnace of the Chairman (Mr. Lorimier) on the Fever river. It was fortified, as was also General Jones' furnace at insinawa, where they also camped. He lived with Mr. Langworily before a white man was in Iowa. In all his incercourse with him he found a generous companion and a rrue man. Mr. L. never shirked a duty, never refused to aid a trne friend, and was "lookad-up to" by the old settlers as oue of their best advisers.

Platt Smith moved that a copy of the resulution - be presented to the family of the deceased, and that they also be published in the daily papers.

Mr. Richard Waller said he came to Galena in 1824, and 
then saw Mr. Langworthy, but that he did not become acquainted with him unril 1837. He then learned to esteem him, and the news of his death shocked him. Mr Waller closed with a strong appeal to the old settlers to try and meet each other in Heaven.

Judge Burt did not claim to be a very old settler. He had known Mr. Langworthy sixteen years. He had secn him as. sising in city enterprises, and forwarding the interests of the city. Rith zeal. His character was fully represented in the resolutions. Le alluded to the sudilenness of the bereavement, and said that in a few years all the old setclers will have gone to their long h ines. It behooved every man to be prepared.

Rev. J. R. Goodrich came here in 1837. He had alwass respected $\mathrm{Mr}$. Langworhy as an upright and h-nor..ble citizen. One trait in Mr. L's. character was worthy of ali commendation-his word was as youd as his bond. When he made an engagement of any kind he met it as fully as thugh he stood pledged over his own signature. Mi. G. expressed himself pleased with the resolutions.

Gen. Wiltse said he was not exactly within the pale of those who most titingly represent the old settlers on this occasion. Hehad knwwn Mr. Langworthy only twenty-tive yrars, and had always considered him an upright and honorable citizen, as well as a frank, outspoken man. He referred to Mr. L's. early career-his coming liere when no smone curled fi,$m$ the white man's cabin, when all was a willemess. He saw the first grave dug, the first school house built, the first church erected, in all this region. From the first he leat a willing hand and a resolute lisart to the work of building up civiization and society. Everything that was dear t. us as property and in local pride, Mi. L. had helped to develop. Gen. W. remurkel that in but few places on esth could such a mesting as this be gatherel. The old settlers east of us have ling since passed away. Mr. Langwor hy came to, Dubuque just as the line was being diawn b tween the sarage and civilized life in the We-t; an 1 his death is near another boundary, not so strong in contrast, but still strongly maked-the line which 
Beparates the age of endurace, privation and heroism from the age of learning and !uxury.

Dr. Mason called the attention of the meeting to the Committee on Biography, called fir by the 5 th resolution.

The Chair app inted Messrs. Mason, Lewis, Emerson, Wiltse, and Bur as such Committee.

Judye King prop ssed an Old Selllers's meeting at some future time, and the oryanization of the Old Settlers socirty.

Dr. Mason said that this is the time to organize such a Scciety. Ile had never hoped to see such a meetingas this. $\mathrm{H}_{\theta}$ offered a resolution to that effect which was carried.

Gen. Jones moved that the names of each old settler pres. ent be handed to the -ecretary. Carried.

Mr. Hardie thought the time at which a man should be considered an old setiler should not be later than $18+6$, or after the State was admitted.

Mr. Young urged the formation of the Society as sonn as possioble.

Here Mr. A. Levi entcred the meeting. He said he wishod to say a few words in regard to the decensed. He came liere in 1833, and had known $\mathrm{VIr}$. Langworthy ever since. He was a perfietly honorable man. Ther was a time in the early history of this region when a man was respec ed in accordance with the amount of whisky he drank and the money he gam. bled away. Mr. Langwoitlyy never drank whirky and never gambled. Ile remeinbered how highly the miners respected him, and $m$ uny were the difi sul ies between them he hud settled when called "fon to judge be ween disputants.

Gen. Lewis and Mr. Treanor thonght Mr. Levi's renarks were calcu ated to cast a shadow upon the reputation of the old settlers. Men were respecte in the early days for good bohavior and sobriety and not for drunkenness and as gamblers.

Mr. Le: i qualified his remarks. Of course he alluded to the hard cases who were numeruus, and who had long since passed away.

On motion of Mr. J. H. Emerson, the meeting adjourned. 
Early Setrlers' Association.-Immediately after the adjournment of the above meeting.the 0 id Settlers again came to order, for the purpose of organizing an Assnciation.

On motion, P. A. Lorimier was called to the Chair, and Mr. C. Childs acted as Secretary.

On motion of Dr. Mason, it was resolved that measures be taken to form an Association of Early Settlers with a view to future incetings.

On motion of Gen. Jones. John King, Timothy Mason and H. L. Stout were appointed a commitiee to prepare by-laws for such an organization, and to call a meeting at su:h time and place as they may deein proper. Adjourued.

\section{A CHAPTER FROM THE UNPUBLISHED HISTORY OF IOIVA CITY.}

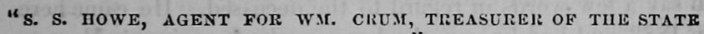
UNIVERSITY."

The Board of Trustzes of the State University, having learned from an elaborately prepared biographical norice of this distinguished individual, from the pen of the editor of the Republican, that there was an ardent wish hlat the former gentleman might be relieved of his self-impised duties, and "form such new relations as that he might h ive busingss to attend to at hume, and thereby be induced to let others al.ne," and wishing to afford him ample time to accomplish tiis laudable undertaking, "a consummation devoutly to be wished," and to look af:er the new responsibilitic's likely to demand his " fal herly" care, REPFaLed the fullowing resulution heietufore passad, that hereafier no doubt might exi-t to perplex the gentleman or his firiends as to where the cumna slivalu be placed ;

"Piesolved, That except where otherwise specially provic ed $[$, originally] hereatter $[$, Huwe] the general superrs lelon of the properiy, buildings and grounds of the state University is 
Copyright of Annals of Iowa is the property of State of Iowa, by \& through the State Historical Society of Iowa and its content may not be copied or emailed to multiple sites or posted to a listserv without the copyright holder's express written permission. However, users may print, download, or email articles for individual use. 